\title{
最適な容積規制と用途規制：各用途および用途間に発生する外部不経済の適正化*
}

\section{A Study on the Design of Optimal Floor Area and Land Use Regulation*}

\author{
河野達仁 $* *$. 森田有一***
}

By Tatsuhito KONO **, Yuichi MORITA ***

\section{1. はじめに}

都市の人口増加は交通混䧱や騒音等の環境悪化といっ た外部不経済を生む. 外部不経済は市場均衡では適正化 されないため，何らかの政策が必要となる．代表的な最 善政策として, Pigou 税がある. しかし, Pigou 税は, 税徵収費用が大きくなり現実的でない，例えば，交通混 雑に対する Pigou 税（i.e., 最善の混雑料金）課税には 時々刻々と変化する混雑税計算が必要であり, かつ料金 徵収システムの構築が必要となる. また, 騒音に対して も同様に，多くの騒音計測システムの設置が必要で，さ らに料金徵収システムの構築が必要である.

そこで，床面積市場，敷地面積市場を規制し，人口分 布を調整する土地利用規制が人口密度に応じて発生する 外部不経済に対処する一つの有効な施策となる．ただし， 土地利用規制は外部性のある市場を直接規制する政策で はないため，最善経済を達成できず次善政策である，な お，土地利用規制は，単独政策としてだけでなく，最善 でない Pigou 税（例：不完全な混雑税）の補完政策とし ても有用である.

本論文では都市部における土地利用規制について考察 する．土地利用に関する既存研究の多く例えば 1),2,3,4, は容積 率規制やMinimum lot size zoning による都市構造や所 得分配構造変化を中心に分析しており, 最適な土地利用 規制を考察していない．例外として，Wheaton ${ }^{5}$ は地点 ごとに異なる Minimum lot size zoning を通勤混雑のあ る Alonzo モデルで検討している. しかし, lot size zoning の分析に限られており, 容積規制については対象 外である. そのような中で，河野他 ${ }^{6)}$ ，Kono et. al ${ }^{7}$ お よび Joshi and Kono ${ }^{8)}$ は閉じた都市（i.e., 人口が外生 である都市）を仮定してゾーンごとに最適な容積規制を

\footnotetext{
*キーワーズ : 計画基礎論，環境計画，土地利用

**正員, 正員, 博(学術), 東北大学大学院情報科学研究科

( T980-8579,仙台市青葉区荒巻字青葉6-3-09 Tel 022-795-4477)

***正員, 修上(情報科学) 国土交通省

（干100-8918 千代田区霞ヶ関2-1-3, Tel 03-5253-8111）
}

導出している．その結果，外部不経済が他ゾーンに比較 して小さいゾーンには，通常用いられる最高容積率規制 ではなく，最低容積率規制が一般的な状況では必要なこ とを示している.

しかし，河野他 ${ }^{6)}$ ，Kono et. al ${ }^{7}$, Joshi and Kono ${ }^{8}$ の いずれも床面積用途を居住用のみと仮定している．実際 の都市におけるビルは事業用や居住用をはじめとして 様々な用途で利用され，用途別に主体の属性が従業者や 居住者などと異なる．そして，人口集中によって発生す る外部不経済要因（混雑，騒音等）の質や量は集中する 主体の属性（例えば，居住者，従業者）によって異なる. 次に，その外部不経済要因が各主体に与える影響，すな わち外部不経済についても受け手の属性（居住者と従業 者）によって大きく異なる．また用途（例えば，居住， 事業等）が異なると，床面積需要の価格弾力性が異なる など需要関数が異なる. 実際の都市計画ではこのような 用途間の異質性を考慮するため，用途別規制がなされて いると考えられる.

そこで都市計画法の第 2 章第 1 節を見ると，用途地域 （いわゆるゾーニング）に関して，その位置および区域 を定め，さらに用途地域別にその建ぺい率や容積率等を 定めるとしている．用途地域における区域設定は，用途 別の総敷地面積を設定することである．また，これらの 設定の目的として，「良好な住居の環境を保護」，「業 務の利便の増進を図りつつ，これと調和した住居の環境 を保護」などがあげられている。

そこで本研究は，都市計画における用途地域の設定の うち，容積率規制と用途別総敷地面積規制を対象に分析 を行う。また，都市計画で用途地域設定の目的とされて いるものを，密度増加による環境覀化や用途相互間の影 響を考慮したうえでの社会的厚生の最大化と位置付ける. 具体的には，閉じた都市を考え，都市内の人口分布の調 整により外部不経済適正化を行うための事業用，居住用 それぞれの最適総床面積規制，総敷地面積規制を求める.

ここまで土地利用密度規制を都市における外部不経済 
の適正化のための規制として話を進めてきた．実際，従 来の土地利用規制研究のほとんどは, 外部経済でなく外 部不経済を対象にしている例外して9)。ただし，都市におけ る事業所には, 従業者の近接性から発生寸る集積の経済 が存在し。これは従業者の密度から発生寸る正の外部経 済である. 一方で従業者の集積による道路混雑などの負 の外部性もある. したがって, 従業者の密度から発生す るその正の外部性と負の外部性（例 : 道路における混雑 など）を比較することで，ゾーンの純外部性の正負が明 らかになる. 現実の都市でこの正負いずれになるかは都 市のインフラをはじめとする都市状況に依存する. 本研 究では, 具体的な分析のために, 負の外部性, 寸なわち 外部不経済が外部経済を上回っている状況を分析する. ただし，仮に逆の場合であっても，同様に議論展開でき る. ただし，規制の方法が変化するため，その変化につ いては4.結論において述べる.

具体的なモデルとして，地理的条件の異なる 2 ゾーン からなる都市を想定し, 各ゾーンに居住用ビルと事業所 用ビルが存在するモデルを構築し, 規制による不効率と 外部不経済削減効果との関係を明示化して, 用途別最適 人口密度を導く規制を考察する. 政策変数は 2 ゾーンそ れぞれの居住用および事業所用の総床面積供給量, さら に居住用および事業所用の総敷地面積供給量である.

\section{2. モデル}

\section{(1)モデルの概要とその現実的意味合い}

具体的に分析を行うためにはモデルを定式化する必要 がある. 本節はモデルの定式化の概要とその現実的意味 合いや解釈を説明する.

モデルは 2 つのゾーンを持ち, それぞれのゾーンに居 住用と事業用の 2 つの用途のビルが存在する. 本研究の 政策変数は 2 つのゾーンそれぞれの用途別総床面積と用 途別総敷地面積である.

1.に示したように, 日本の地域地区制（ゾーニン グ）では，用途規制と同時に容積率規制が行われている. ここで，用途規制では，用途別総敷地面積を規制してお り，容積率規制は，用途別総床面積を規制している．実 際, 用途別総床面積を用途別総敷地面積で除すと用途別 容積率となる. ここで, 本研究の政策変数は用途規制と 容積率規制である.

モデルには以下のような仮定がある.

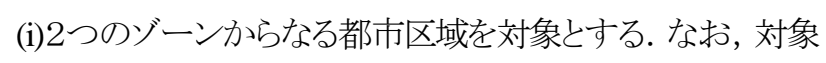

区域の面積は固定されている. 現実的な例としては，線 引きされた市街化区域や, 地理的条件から都市の面積 が広げられない都市（例：シンガポールやカトマン ズ）を想定できる.

(ii) $2 つ の$ 地理的条件の異なるゾーン $(i=1,2)$ が存在し， 各ゾーンの敷地面積はそれぞれ $\bar{A}_{1}, \bar{A}_{2}$ で固定され ている. 現実の都市には, 地理的条件の異なるゾー

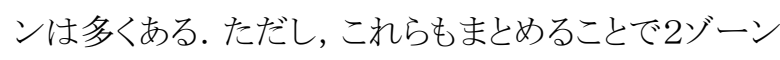
で表現可能である.

(iii)主体として個人, 事業所, Developer が存在する. す べての居住者は同質であり，事業所も同質である。 ま た，事業所も Developer も，生産財および投入財すべて の価格が，それぞれの主体に与件であるとする.すな わち，完全競争を仮定する．この仮定は，同質財を供 給する事業所やDeveloper が多く存在する都市では成立 している.

(iv)すべての個人が労働を行う．また，すべての個人が土 地を平等に保有していると仮定して，土地収入が等分 に個人に分配される public ownership の仮定を置く.

(v)ゾーン間の移住コストは, 分析の簡単化のために存在 せず，居住者は効用水準の高いゾーンに移住する。 ま た，通勤費用や転職費用もゼロで従業者は賃金の高い 事業所で㗢く.すなわち，長期均衡を想定する.

(vi)道路等の社会資本の水準は固定されている. ただし， その水準は任意であり, 社会資本整備の純便益が最大 となる最適水準も含む.

(vii)両ゾーンは地理的条件の異なるゾーンである. そのた め, 人口密度規制がないもとでも等人口密度にはなら ない. なお, 地理的要因には都心までの距離も含む。

(viii)最適土地利用規制は，両ゾーンの個人（地主も兼ね る個人）の効用の総和を最大にする規制とする.

(viiii)外部不経済は, ゾーン人口に応じたものを対象とす る. ゾーン人口に応じて発生する外部不経済の代表例 として, 交通混雑や騒音がある. 具体的には各ゾーン の外部不経済要因（混雑, 騒音等) がそれぞれのゾー ンの居住者数およびゾーンの従業者数に依存して発生 すると仮定する，ただし，居住者・従業者それぞれが 生み出寸外部不経済要因（混雑，騒音等）の大きさは 異なりうるものとする. また各ゾーンで発生する外部 不経済要因は当該ゾーンの居住者にも, 企業にも不経 済を与える，そのとき，与える外部不経済の質や量は 居住者に対するものと企業に対するものでは異なりう 
るものとする．現実にも，業務で発生する騒音は，住 民と企業には異なる影響を及ぼす，また，交通混䧱も 各主体に与える影響は異なる。

\section{（2） モデル}

\section{a) 外部不経済要因}

$i$ ゾーンで発生する外部不経済要因（混䧱, 騒音等) $g^{i}$ は式(1a)で示すように各ゾーンの居住人口 $N^{i}$, 従業 人口 $L^{i}$ に応じて発生する. 寸なわち, ゾーンの外部不経 済要因は居住人口および従業人口の増加により増加する。

$$
g^{i}=g\left(N^{i}, L^{i}\right)
$$

ただし， $i=1,2$ はそれぞれゾーン 1 とゾーン 2 を 示す.ここで, $g_{N^{i}}^{i}>0, \quad g_{L^{i}}^{i}>0$ を仮定する. な お， $g_{N^{i}} \equiv \partial g^{i} / \partial N^{i}, \quad g_{L_{i}}^{i} \equiv \partial g^{i} / \partial L^{i}$ であり，論文 を通じてサブスクリプトは，その変数による微分を 表すこととする. 式(1)と同様の外部不経済の設定 としては, Fujita(1989) ${ }^{10)}$ が居住人口に応じて発生す る外部不経済要因を取り扱っている。なお， 1。で 示したように $g^{i}$ は外部経済（e.g.集積の経済）と外 部不経済の和, 寸わなち純外部性を表現したものと 解釈しても問題ない，その場合の結果の解釈につい ては，4，で考察する.

外部不経済要因（混雑, 騒音等）について，住民 と企業で発生メカニズムや発生量が異なりうること を式(1)で一般的に表現している. なお, 式(1)の $g^{i}$ はスカラーであり, 一種類の外部不経済要因として 表現している.ただし, $g^{i}$ をべクルとして, 複 数の外部不経済要因が発生することを考慮しても, それぞれが人口密度に応じて変化する外部性である 限り, 以降の分析や分析結果に本質的な違いはない. ここでは, 表記の簡単化のために, $g^{i}$ をスカラー として分析を行う.

\section{b）個人の行動}

個人の行動は式(2a)，(2b)で表される. 式(2a)に示すよ うに，準線形の効用関数を分析の簡単化のために仮定す る. 効用関数は居住者の床面積需要 $f^{\text {ih }}$, 居住するゾー ンの外部不経済要因 $g^{i}$, ゾーン固有の魅力 $\bar{e}^{i}$ の関数で ある. ゾーン固有の魅力 $\bar{e}^{i}$ は固定されている. ゾーン固 有の魅力 $\bar{e}^{i}$ の例としては, 鉄道駅の有無や社会資本整備 レベルであり，この変数がゾーン間で異なることからゾ ーン間の人口密度が変化する，なお，ゾーン固有の魅力 $\bar{e}^{i}$ には，住民や企業の分布に応じて変化する集積の魅力 は含まない，住民や企業が発生させる外部不経済要因 $g^{i}$ の住民への影響が効用関数(2a)で表現されている. 式(2c) は, その影響の性質, 具体的には効用関数の一階微分と 二階微分を表しており，第一式は外部不経済要因 $g^{i}$ が居 住者に外部不経済（悪影響）を与えることを示し，第二 式は外部不経済要因と床面積供給量は効用変化に対し互 いに独立であることを示す.さらに第三式は外部不経済 要因の効用一の悪影響が聥増的であることを示している. 第二式の性質は，例えば床面積の消費拡大で得られる限 界効用が混雑や騒音などに影響されないことを意味して いる.

なお以下，スーパースクリプト $h, f, d$ はそれぞれ，個 人，事業所，Developer に関する変数であることを示す. 例えば， $\overline{\bar{a}}^{\text {ih }}$ は敷地面積の用途として居住用途であること を示す.ここで, 変数の上の一重線は, その変数が外生 変数であることを，二重線は政策変数であることを示す．

$$
\begin{gathered}
V^{i}=\max _{x^{i h}, f^{i h}} u\left(f^{i h}, g^{i}, \bar{e}^{i}\right)+x^{i h} \\
\text { s.t. } x^{i h}+r^{i h} f^{i h}=w^{i}+\frac{1}{\bar{N}}\left\{\sum_{i} \pi^{i f}+\sum_{k=h, f} \sum_{i} \pi^{i k k}+\sum_{k=h, f} \sum_{i} R^{i k} \bar{a}^{i k}\right\} \\
u_{g^{i}}^{i} \leq 0, \quad u_{f^{i} g^{i}}^{i}=0, \quad u_{g^{i} g^{i}}^{i} \leq 0
\end{gathered}
$$

ただし, $x^{\text {ih }}: i$ ゾーンの各家計の合成財需要, $\overline{\bar{a}}^{i k}: i$ ゾーンの用途 $k$ の総敷地面積供給量, $r^{i k}: i$ ゾーン の用途 $k$ の床面積価格, $w^{i}: i$ ゾーンの賃金, $R^{i k}: i$ ゾーンの用途 $k$ の地代, $\bar{N}$ : 都市総人口, $(i=1,2), \quad f^{i k}: i$ ゾーンの用途 $k$ の一市たりの床面 積需要, $\pi^{i f}: i$ ゾーンの事業所の利潤, $\pi^{i d k}: i$ ゾ ーンの用途 $k$ のビル建設を行う Developer の利潤で ある。また $, u_{g^{i}}^{i} \equiv \partial u^{i} / \partial g^{i}, u_{f^{i} g^{i}} \equiv \partial^{2} u^{i} / \partial f^{i} \partial g^{i}$ ， $u_{g^{i} g^{i}} \equiv \partial^{2} u^{i} / \partial g^{i 2}$ である.

\section{c）事業所の行動}

i ゾーンに存在する事業所は式(3a)に示寸利潤最大化行 動をとる. 生産関数は式(3b)に示されるように当該ゾー ンの従業者数, 床面積需要, 外部不経済原因（混雑, 騒 音等) $g^{i}$ の関数とする.

$$
\begin{aligned}
& \pi^{i f}=\max _{x^{i f}, L_{i}^{i}}\left\{X^{i f}-w L^{i}-r^{i f} f^{i f}\right\} \quad(i=1,2) \quad(3 \mathrm{a}) \\
& \text { s.t. } \quad X^{i f}=X^{i f}\left(L^{i}, f^{i f}, g^{i}\right) \quad(i=1,2)
\end{aligned}
$$

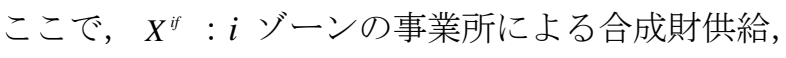

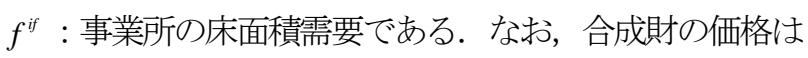
1 とする.

式(3a)，(3b)の一階条件から式(3c)が導かれる. なお, 従業者数 $L^{i}$ と床面積需要量 $f^{i f}$ に関して一次同次の生産 関数を仮定する. その結果, 事業所の利潤 $\pi^{i f}$ は常に 0 
になる．なお，外部不経済原因（混雑，騒音等） $g^{i}$ に関 して生産関数は必ずしも一次同次でなく, 外部不経済要 因は生産に非線形的に影響を与えうる。

$$
X_{L^{i}}=w^{i} \text { and } X_{f^{i f}}=r^{i f}
$$

なお， $\quad X_{L^{i}}{ }^{i} \equiv \partial X^{i f} / \partial L^{i}, \quad X^{i f}{ }_{f^{i}} \equiv \partial X^{i f} / \partial f^{i}$. 住民や企 業が発生させる外部不経済要因 $g^{i}$ が事業所に与える影響 は，生産関数(3b)の第 3 番目の説明変数で表されている. 費用関数 $C^{\text {if }}$ は式(3e), (3f)のように示される.

$$
\begin{aligned}
& C^{i f}=\min _{L^{i}, f^{i t}}\left\{w^{i} L^{i}+r^{i f} f^{i f}\right\} \quad(i=1,2) \\
& \text { s.t. } \quad X^{i f}=X^{i f}\left(L^{i}, f^{i f}, g^{i}\right) \quad(i=1,2)
\end{aligned}
$$

\section{d) Developer の行動}

Developer は複数存在する．ただし，完全競争である ため，一つの Developer として定式化できる. また，用 途 $k$ 別にモデル化する. Developer は式(4a)で示されるよ うな価格与件の利潤最大化行動をする. 式(4b)は床面積 生産関数を表す． $\overline{\bar{F}}^{i k}$ は，用途別総床面積規制により指 定されるため, デベロッパーにとって外生変数である.

$$
\begin{aligned}
& \pi^{i d k}=\max _{x^{i d k}}\left\{r^{i k} \overline{\bar{F}}^{i k}-\left(x^{i d k}+R^{i k} \overline{\bar{a}}^{i k}\right)\right\} \\
& \text { s.t. } \quad \overline{\bar{F}}^{i k}=\overline{\bar{F}}^{i k}\left(x^{i d k}, \overline{\bar{a}}^{i k}\right) \quad(i=1,2)
\end{aligned}
$$

ここで, $\overline{\bar{F}}^{i k}$ : $i$ ゾーンの用途 $k$ の総床面積供給量, $x^{i a k}:$ Developer の $i$ ゾーンの居住用または事業用ビル の建設に投入される合成財需要である.

式(4b)は右辺の $x^{i a k}$ について解くと式(4c)のように 書き換えられる.

$$
x^{i d k}=x^{i d k}\left(\overline{\bar{F}}^{i d k}, \overline{\bar{a}}^{i k}\right)
$$

式(4c)を用いると, 用途別ビル建設の Developer の利潤最大化式(4a), (4b)は, 結局, 式(4d)で表され る.

$$
\pi^{i d k}=r^{i k} \overline{\bar{F}}^{i d k}-x^{i d k}\left(\overline{\bar{F}}^{i d k}, \overline{\bar{a}}^{i k}\right)-R^{i k} \overline{\bar{a}}^{i k}
$$

\section{e）市場均衡}

市場均衡条件として，合成財，床面積，敷地面積，従 業人口および住民の需給均衡が成立する，また，各家計 は個人の効用水準の高いジーンに移住することから，均 衡では両ゾーンの効用水準が等しくなる. さらに，従業 員は賃金の高い事業所へ移動するため，均衡では両ゾー ンの賃金が等しくなる.

\section{（3）厚生の変化}

個人はすべて同質であるから，個人の効用最大化と， 社会的厚生 $B\left(=\sum_{i} N_{i} V_{i}\right)$ の最大化は同義である.

ここで社会的厚生 $B$ の変化を経済変数で表現する，社 会的厚生の変化 $d B$ は個人, 事業所, Developer の行動之 市場均衡を用いると，式(6)のように導出される.

$$
\begin{aligned}
d B= & \left(N^{1} u_{g^{1}}^{1} g_{N^{1}}^{1}-N^{2} u^{2}{ }_{g^{2}} g^{2}{ }_{N^{2}}\right) d N^{1} \\
& +\left(N^{1} u_{g^{1}}^{1} g_{L^{1}}^{1}-N^{2} u^{2}{ }_{g^{2}} g^{2}{ }_{L^{2}}\right) d L^{1} \\
& -\left(C^{1 f}{ }_{g^{1}} g_{N^{1}}^{1}-C^{2 f}{ }_{g^{2}} g^{2}{ }_{N^{2}}\right) d N^{1} \\
& -\left(C^{1 f}{ }_{g^{1}} g_{L^{1}}^{1}-C^{2 f} g_{g^{2}} g_{L^{2}}^{2}\right) d L^{1} \\
& +\sum_{i k} \sum_{k}\left[r^{i k}-x^{i d k} \overline{\bar{F}}^{i k}\right] d \overline{\bar{F}}^{i k}-\sum_{i}\left[x_{\overline{\bar{a}}^{i h}}-x^{i d f} \overline{\bar{a}}^{i f}\right] d \overline{\bar{a}}^{i k}
\end{aligned}
$$

式(6)の各項の意味をそれぞれ次に述べる.

1 項目 $\left(N_{1} u_{{ }^{1}}{ }^{1}{ }^{1}{ }_{N^{1}}-N_{2} u^{2}{ }_{g^{2}} g^{2}{ }_{N^{2}}\right) d N_{1}$ : ゾーン 2 からゾー ン 1 への居住者移住 $d N_{1}$ によるゾーン 1 とゾーン 2 の居 住者に対する外部不経済変化の総和.

2 項目 $\left(N_{1} u_{g^{1}}{ }^{1} g_{L^{1}}^{1}-N_{2} u^{2}{ }_{g^{2}} g^{2}{ }_{L^{2}}\right) d L_{1}:$ : ーン 2 からゾーン 1 への従業者の従業地移動 $d L_{1}$ によるゾーン 1 とゾーン 2 の居住者に対する外部不経済変化の総和.

3 項目 $-\left(C^{1 f}{ }_{g^{1}} g_{N^{1}}^{1}-C^{2 f}{ }_{g^{2}} g^{2}{ }_{N^{2}}\right) d N_{1}$ : ゾーン 2 からゾー ン 1 への居住者移住 $d N_{1}$ によるゾーン 1 とゾーン 2 の事 業所に対する外部不経済変化の総和.

4 項目 $-\left(C^{1 f}{ }_{g^{1}} g_{L^{1}}^{1}-C^{2 f}{ }_{g^{2}} g_{L^{2}}^{2}\right) d L_{1}$ : ゾーン 2 からゾーン 1 への従業者の従業地変更 $d L_{1}$ によるゾーン 1 とゾーン 2 の事業所に対寸る外部不経済変化の総和.

5 項目 $\sum_{i k} \sum_{k}\left[r^{i k}-x^{i d k}{ }_{\overline{\bar{F}}}^{i k}\right] d \overline{\bar{F}}^{i k}$ : 床面積価格 (逆需要)

$r^{i k}$ 曲線と床面積限界費用 $x^{i k} \overline{\bar{F}}^{i k}$ 曲線との差に $d \overline{\bar{F}}^{i k}$ を乗 じたもの（i.e., 床面積市場における死加重変化）.

6 項目 $\sum_{i}\left[x^{i d h} \overline{\bar{a}}^{i h}-x^{i d f} \overline{\bar{a}}^{i f}\right] d \overline{\bar{a}}^{i k}:$ 各ゾーンでの住居 用敷地面積変化 $d \overline{\bar{a}}^{i k}$ による住居用ビルの限界費用 $x^{i d h}{ }_{\overline{\bar{a}}}{ }^{i h}$ と事業所用ビルの限界費用 $x^{i d f} \overline{\bar{a}}^{i f}$ の差に $d \overline{\bar{a}}^{i k}$ を乗じたも の (i.e., 用途別総敷地面積規制による死加重変化).

なお 1 項目から 4 項目までの（）内を表記の簡単化の ため以下に定義する $\Delta G^{H H}, \Delta G^{H O}, \Delta G^{O H}, \Delta G^{O O}$ で表す.

$$
\begin{aligned}
& \Delta G^{H H} \equiv N^{1} u_{g^{1}}^{1} g_{N^{1}}^{1}-N^{2} u_{g^{2}}{ }^{2}{ }_{N^{2}} \\
& \Delta G^{O H} \equiv N^{1} u_{g^{1}} g_{L^{1}}^{1}-N^{2} u^{2}{ }_{g^{2}} g^{2}{ }_{L^{2}} \\
& \Delta G^{H O} \equiv C^{1 f}{ }_{g^{1}} g_{N^{1}}^{1}-C^{2 f}{ }_{g^{2}} g^{2}{ }_{N^{2}} \\
& \Delta G^{O O} \equiv C^{1 f}{ }_{g^{1}} g_{L^{1}}^{1}-C^{2 f}{ }_{g^{2}} g_{L^{2}}^{2}
\end{aligned}
$$


$\Delta G^{H H}$ におけるスーパースクリプト $H H$ は家計

(Households) のゾーン 2 からゾーン 1 への移動で発生 する外部不経済要因（例 : 混雑や騷音）がゾーン 1 とゾ ーン 2 の家計（Households）に与える影響であることを 示寸. 同様に, $\Delta G^{\mathrm{HO}}, \Delta G^{\mathrm{OH}}, \Delta G^{\mathrm{OO}}$ はそれぞれ, 家 計の外部不経済要因が企業（Offices）に与える影響, 企 業 (Offices) の外部不経済要因が家計 (Households) に与 える影響, 企業 (Offices) の外部不経済要因が企業 (Offices) に与える影響を表す.

\section{3. 最適容積率規制および敷地面積規制}

\section{(1) 最適条件式}

社会的厚生 $B$ を最大化するように規制されるゾーン別 用途別総床面積供給量 $\overline{\bar{F}}^{1 h}, \overline{\bar{F}}^{1 f}, \overline{\bar{F}}^{2 h}, \overline{\bar{F}}^{2 f}$ とゾーン別用 途別総敷地面積供給量 $\overline{\bar{a}}^{1 h}, \overline{\bar{a}}^{2 h}, \overline{\bar{a}}^{1 f}, \overline{\bar{a}}^{2 f}$ を最適総床面積, 最適総敷地面積と定義する。（なお, 各ゾーンの最適用 途別総床面積供給量を各ゾーンの最適用途別総敷地面積 供給量で除すと, 最適容積率が得られる.)

社会的厚生 $B$ をゾーン別用途別総床面積, および用途 別総敷地面積を变数として最大化するため必要条件はク ーン・タッカーの 1 階条件より, 式(7a),(7b)のように示 される.

$$
\begin{aligned}
& \overline{\bar{F}}^{i k}\left\{\frac{\partial B}{\partial \overline{\bar{F}}^{i k}}\right\}=0, \frac{\partial B}{\partial \overline{\bar{F}}^{i k}} \leq 0 \\
& \overline{\bar{a}}^{i k}\left\{\frac{\partial B}{\partial \overline{\bar{a}}^{i k}}\right\}=0, \frac{\partial B}{\partial \overline{\bar{a}}^{i k}} \leq 0
\end{aligned}
$$

式(7a),(7b)を満たす用途別総床面積供給量 $\overline{\bar{F}}^{1 h}, \overline{\bar{F}}^{1 f}, \overline{\bar{F}}^{2 h}, \overline{\bar{F}}^{2 f}$ および用途別総敷地面積供給量 $\overline{\bar{a}}^{1 h}, \overline{\bar{a}}^{2 h}, \overline{\bar{a}}^{1 f}, \overline{\bar{a}}^{2 f}$ が最適規制である.

ここで， $\overline{\bar{F}}^{i k}=0$ は $i$ ゾーンに $k$ 用途の床面積がまった く供給されないことを示す. 一方, $\overline{\bar{a}}^{i k}=0$ は $i$ ゾーンに $k$ 用途の敷地面積がまったく供給されないことを意味し ている. 本研究は, 都市計画における用途地域 (ゾーニ ング）を分析対象としており, 用途の異なる主体が同じ ゾーンで外部不経済を通して相互に影響しあう状況を想 定している.ここで, $k$ 用途の敷地面積がゾーンにまっ たく供給されない状況を想定すると, その相互の影響を 考慮できないため, $\overline{\bar{F}}^{i k}=0, \overline{\bar{a}}^{i k}=0$ が最適解になる状 況はないと仮定寸る. つまり, 内点解として最適解が存 在することを仮定する。結局, $\partial B / \partial \overline{\bar{F}}^{i k}=0$ および $\partial B / \partial \overline{\bar{a}}^{i k}=0$ が最適解の条件となる. 最適解の条件に式 (6g)を代入すると, 用途別総床面積に供給量に関する一階 条件は式(7c) となる. 用途別総敷地面積は式(7d) となる. なお， $\overline{\bar{a}}^{i h}+\overline{\bar{a}}^{i f}=\bar{A}^{i}$ (一定) を用いると $\overline{\bar{a}}^{1 h} ， \overline{\bar{a}}^{2 h} ， \overline{\bar{a}}^{1 f} ，$ $\overline{\bar{a}}^{2 f}$ を変数として社会的厚生を最大化することは $\overline{\bar{a}}^{1 h}, \overline{\bar{a}}^{2 h}$ を変数として，最大化することになるため，式 (7d)は $\overline{\bar{a}}^{1 h}, \overline{\bar{a}}^{2 h}$ のみの条件となっている.

\section{用途別総床面積に関する最適条件式：}

$$
\begin{aligned}
\frac{\partial B}{\partial Z^{i k}} & =\Delta G^{H H} \frac{d N^{1}}{d Z^{i k}}-\Delta G^{H O} \frac{d N^{1}}{d Z^{i k}}+\Delta G^{O H} \frac{d L^{1}}{d Z^{i k}}-\Delta G^{O O} \frac{d L^{1}}{d Z^{i k}} \\
& +r^{i k}-\frac{\partial X^{i d k}}{\partial Z^{i k}}=0 \quad\left(Z^{i k}=\overline{\bar{F}}^{1 h}, \overline{\bar{F}}^{1 f}, \overline{\bar{F}}^{2 h}, \overline{\bar{F}}^{2 f}\right)
\end{aligned}
$$

用途別総敷地面積に関する最適条件式 :

$$
\frac{\partial B}{\partial \overline{\bar{a}}^{i h}}=\frac{\partial x^{i d h}}{\partial \overline{\bar{a}}^{i h}}-\frac{\partial x^{\text {idf }}}{\partial \overline{\bar{a}}^{i f}}=0 \quad(i=1,2)
$$

式(7c), (7d)を同時に満たす政策が社会厚生を最大化す る.つぎに, 用途別総床面積, 用途別総敷地面積の最適 規制方法を別々に検討する.

\section{（2）最適条件式を満たす用途別総床面積規制}

最適な床面積規制の性質を考察するため床面積供 給量の市場均衡からの乘離を示す $\tilde{F}^{i k}$ を新たに定義 する． $\tilde{F}^{i k}$ は図-1で示すように規制されている総床 面積供給量が市場均衡の総床面積と比べ多いか少な いかを示す． $\tilde{F}^{i k}>0$ であれば，市場均衡より大き く総床面積を規制し， $\tilde{F}^{i k}<0$ であれば市場均衡よ り小さく総床面積を規制する必要がある.

ここで最適条件式(7c)を満たす床面積供給量が市 場均衡よりも大きいか小さいかを検討し, 最適用途 別総床面積規制を求める. 表記の簡単化のため(7c) の右辺の一部を $d Y / d Z^{i k}$ と以下のように定義する.

$$
\frac{d Y}{d Z^{i k}} \equiv \Delta G^{H H} \frac{d N^{1}}{d Z^{i k}}-\Delta G^{H O} \frac{d N^{1}}{d Z^{i k}}+\Delta G^{O H} \frac{d L^{1}}{d Z^{i k}}-\Delta G^{O O} \frac{d L^{1}}{d Z^{i k}}
$$

$d Y / d Z^{i k}$ を用いると, 式(7c)は次のように書ける.

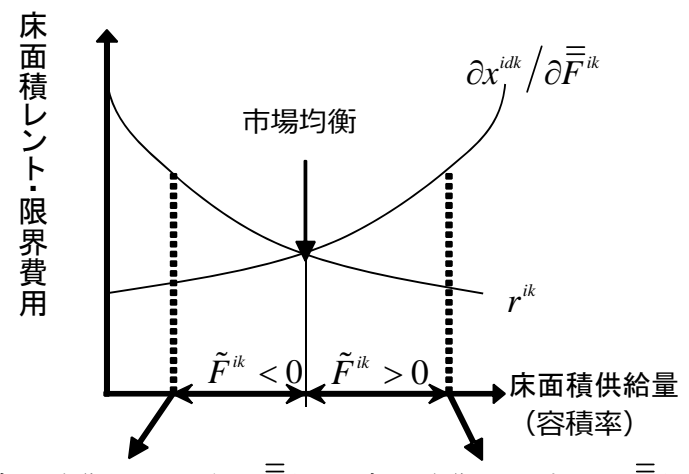

市場均衡より小さい $\overline{\bar{F}}^{i k}$ 市場均衡より大きい $\overline{\bar{F}}^{i k}$

図-1 最適規制と市場均衡 


$$
\frac{\partial B}{\partial Z^{i k}}=\frac{d Y}{d Z^{i k}}+r^{i k}-\frac{\partial x^{i d k}}{\partial Z^{i k}}=0
$$

仮に $d Y / d Z^{i k}<0$ であるとき，式(7c)を満たすには $r^{i k}-\partial x^{i d k} / \partial Z^{i k}$ の值を正にする必要がある。 そのため には図-1で示すように床面積供給量 $\overline{\bar{F}}^{i k}$ を市場均衡 で決まる值より小さくする必要がある。すなわち $\tilde{F}^{i k}<0$ とすると, 床面積価格が床面積の限界費用 を上回り， $r^{i k}-\partial x^{i d k} / \partial Z^{i k}$ が正となる。逆に $d Y / d Z^{i k}>0$ であるとき, 式(7c)を満たすには $\tilde{F}_{i}^{k}>0$ とする必要がある。 $\tilde{F}^{i k}>0$ とする政策の場合，市 場均衡より大きな床面積供給量にするために最低容 積率規制を行う必要がある. $\tilde{F}^{i k}<0$ とする政策の 場合, 市場均衡より小さい床面積供給量にするため に最高容積率規制を行う必要がある。ここで, $d Y / d Z^{i k}$ の符号は，外部不経済の分布パターンで変 化する. そのため, 外部不経済の分布パターン別に 最適規制を検討する。

$d Y / d Z^{i k}$ の符号を調べるためには説明変数である $d N^{i} / d \overline{\bar{F}}^{i k}, d L^{i} / d \overline{\bar{F}}^{i k}, d L^{i} / d \overline{\bar{a}}^{i k}(i=1,2, \quad k=h, f)$ の符号を知る 必要がある。これらは，モデルから導出でき，性質 1 としてまとめられる。（これらは厳密な導出が可 能である。しかし，これらの性質はすべて直感的に も明らかなため，導出過程はここには示さない.）

\section{性質 1 （規制による居住人口，従業人口の変化）}

$d N^{1} / d \overline{\bar{F}}^{1 h}>0, d L^{1} / d \overline{\bar{F}}^{1 h}<0, d N^{1} / d \overline{\bar{F}}^{2 h}<0, d L^{1} / d \overline{\bar{F}}^{2 h}>0$ $d N^{1} / d \overline{\bar{F}}^{1 f}<0, d L^{1} / d \overline{\bar{F}}^{1 f}>0, d N^{1} / d \overline{\bar{F}}^{2 f}>0, d L^{1} / d \overline{\bar{F}}^{2 f}<0$ $d N^{1} / d \overline{\bar{a}}^{1 h}=d L^{1} / d \overline{\bar{a}}^{1 h}=d N^{1} / d \overline{\bar{a}}^{2 h}=d L^{1} / d \overline{\bar{a}}^{2 h}=0$

性質 1 は，容積規制および総敷地面積規制を変化 させた場合のゾーン 1 の居住人口, 従業者数の変化 の符号を示している。一行目は, 住居用床面積を各 ゾーンで増加させたときの居住人口と従業人口の変 化である，ゾーン $i$ で住居用総床面積を増加させる とゾーン $i$ の居住人口は増加し, 従業人口は減少す ることを示している．同様に二行目では，ゾーン $i$ で事務所総床面積を増加させるとゾーン $i$ の居住人 口は減少し，従業人口は増加することを示している。 三行目は住居用総敷地面積を増加（=同面積の事務 所敷地面積の減少）させても, 居住人口, 従業人口 ともに変化がないことを示している。この不変性は
用途別総床面積が規制で固定されているもとで成立 する性質である。

ここでゾーン 1 , ゾーン 2 の外部不経済の空間パ ターンを分類する. まず， 2 つるゾーンのどちら をゾーン 1 と呼ぶかは単なる定義の問題である。す なわち，一般性を失うことなくゾーン番号を与える ことができる。そこで，ゾーン 2 から 1 への居住者 の移動が個人の効用に与える外部性 $\Delta G^{H H}$ と, ゾーン 2 から 1 への居住者の移動が企業の生産に与える外 部不経済 $\Delta G^{H O}$ を比較したとき， $\Delta G^{H H}>\Delta G^{H O}$ となるよ うに, ゾーン 1 と 2 を定義する.これはゾーン 2 か ら 1 への居住者の移動があったとき, その移動が個 人の効用に与える外部不経済 $\Delta G^{H H}$ が企業の生産に与 える外部不経済 $\Delta G^{H H}$ よりも大きいことを示す.

次にゾーン 2 から 1 への従業者の移動が事業所の 生産に与える影響 $\Delta G^{O O}$ と, 家計に与える影響 $\Delta G^{O H}$ と の差分 $\Delta G^{H H}-\Delta G^{H O}$ の值の正負によって場合分けを する. 検討すべき場合分けとして表-1 のケース 1)と 2）が存在する. ケース 1)はゾーン 2 から 1 への従 業者の移動が事業所の生産に与える悪影響が家計に 与える悪影響よりも大きく，ケース 2) は，事業所 の生産に与える悪影響よりも家計に与える悪影響の ほうが大きい，事業所については生産性，家計につ いては快適性が重要であることを考えると，ケース 1）は交通混雑が大きい場合であり，ケース 2）に ついては事業には不可避ながらも生活には不快な騒 音が大きい場合が例としてあげられる.

なお，ケース 1），2）以外にも， $\Delta G^{H H}=\Delta G^{H O}$ や $\Delta G^{\mathrm{OO}}=\Delta G^{\mathrm{OH}}$ となるケースもありうる．ただし， これらは, 偶然しか存在しないため, 本研究ではこ れらのケースについては分析を行わない。

表-1 外部不経済のパターンによる場合分け

\begin{tabular}{|c|c|c|}
\hline & $\Delta G^{H H}-\Delta G^{H O}$ & $\Delta G^{O O}-\Delta G^{O H}$ \\
\hline ケース 1) & + & + \\
\hline ケース 2) & + & - \\
\hline
\end{tabular}

それぞれの場合について最適政策を検討する.

ケース 1) $\Delta G^{\mathrm{HH}}-\Delta G^{\mathrm{HO}}>0$ かつつ $\Delta G^{\mathrm{OO}}-\Delta G^{\mathrm{OH}}>0$

以下で，最適条件式(7c)式を満たす最適な $\overline{\bar{F}}^{1 h}$, $\overline{\bar{F}}^{2 h}, \quad \overline{\bar{F}}^{1 f}, \quad \overline{\bar{F}}^{2 f}$ を順に求めていく.

まず $\overline{\bar{F}}^{1 h}$ について最適条件式(7c) $\left(Z^{i k}=\overline{\bar{F}}^{1 h}\right.$ の場 
合)の符号が判明している項の正負を項の下に示す。

$$
\begin{aligned}
& \frac{\partial B}{\partial \overline{\bar{F}}^{1 h}}=\left(\Delta G_{(+)}^{H H}-\Delta G^{H O}\right) \frac{d N^{1}}{d \overline{\bar{F}}_{(+)}^{1 h}} \\
& -\left(\Delta G_{(+)}^{O O}-\Delta G^{O H}\right) \frac{d L^{1}}{d \overline{\bar{F}}_{(-)}^{1 h}}+r_{1}^{f}-\frac{\partial x^{1 d f}}{\partial \overline{\bar{F}}^{1 h}}=0
\end{aligned}
$$

したがって，第一項目は正，第二項も正となり， $r^{1 h}-\partial x^{1 d h} / \partial \overline{\bar{F}}^{1 h}$ 以外の項は正であるため, 最適条件 式が成立するには， $r^{1 h}-\partial x^{1 d h} / \partial \overline{\bar{F}}^{1 h}<0$ とする必要が ある.したがって, 図-1から, ゾーン 1 の居住床面 積を市場均衡よりも大きく規制しなければならない. 必要な政策は $\tilde{F}^{1 h}>0$ となる政策である.

同様に最適条件式(7c) ( $Z^{i k}=\overline{\bar{F}}^{2 h}$ の場合)の符号が判 明している項の正負を項の下に示す.

$$
\begin{aligned}
\frac{\partial B}{\partial \overline{\bar{F}}^{1 h}} & =\left(\Delta G_{(+)}^{H H}-\Delta G^{H O}\right) \frac{d N^{1}}{d \overline{\bar{F}}_{(-)}^{2 h}} \\
& -\left(\Delta G_{(+)}^{O O}-\Delta G^{O H}\right) \frac{d L^{1}}{d \overline{\bar{F}}_{(+)}^{2 h}}+r^{1 h}-\frac{\partial x^{1 d h}}{\partial \overline{\bar{F}}^{2 h}}=0
\end{aligned}
$$

$r^{2 h}-\partial x^{2 h} / \partial \overline{\bar{F}}^{2 h}$ 以外の項はマイナスであるため, 最 適条件式が成立するためには $r^{2 h}-\partial x^{2 h} / \partial \overline{\bar{F}}^{2 h}>0$ とな ることが必要である. 図-1から, ゾーン 2 の居住床 面積を市場均衡よりも小さく規制しなければならな い. よって必要な政策は $\tilde{F}^{2 h}<0$ となる政策である. 同様に最適条件式(7c)（ $Z^{i k}=\overline{\bar{F}}^{1 /}$ の場合)の符号が判 明している項の正負を項の下に示寸.

$$
\begin{aligned}
\frac{\partial B}{\partial \overline{\bar{F}}^{1 f}} & =\left(\Delta G_{(+)}^{H H}-\Delta G^{H O}\right) \frac{d N^{1}}{d \overline{\bar{F}}^{1 f}} \\
& -\left(\Delta G_{(+)}^{O O} \underset{(+)}{-} \Delta G^{O H}\right) \frac{d L^{1}}{d \overline{\bar{F}}^{1 f}}+r^{1 f}-\frac{\partial x^{1 d f}}{\partial \overline{\bar{F}}^{1 f}}=0
\end{aligned}
$$

$r^{1 f}-\partial x^{1 d f} / \partial \overline{\bar{F}}^{1 f}$ 以外の項はマイナスであるため, 最 適条件式が成立するためには $r^{1 f}-\partial x^{1 d f} / \partial \overline{\bar{F}}^{1 f}>0$ とな ることが必要である。図-1から，ゾーン 1 の事業所 床面積を市場均衡より小さく規制しなければならな い.よって必要な政策は $\tilde{F}^{1 f}<0$ となる政策である. 同様に最適条件式(7c) ( $Z^{i k}=\overline{\bar{F}}^{2 f}$ の場合)の符号が 判明している項の正負を項の下に示す.

$$
\begin{aligned}
\frac{\partial B}{\partial \overline{\bar{F}}^{2 f}} & =\left(\Delta G_{(+)}^{H H} \underset{(+)}{H O}\right) \frac{d N^{1}}{d \overline{\bar{F}}_{(+)}^{2 f}} \\
& -\left(\Delta G_{(+)}^{O O} \underset{\left.-\Delta G^{O H}\right)}{\frac{d L^{1}}{d \overline{\bar{F}}_{(-)}^{2 f}}}+r^{2 f}-\frac{\partial x^{2 d f}}{\partial \overline{\bar{F}}^{2 f}}=0\right.
\end{aligned}
$$

$r^{2 f}-\partial x^{2 d f} / \partial \overline{\bar{F}}^{2 f}$ 以外の項はプラスであるため, 最適 条件式の成立のためには $r^{2 f}-\partial x^{2 d f} / \partial \overline{\bar{F}}^{2 f}<0$ となる
ことが必要である. 図-1から, ゾーン 2 の事業用床 面積を市場均衡よりも大きく規制しなければならな

\begin{tabular}{|c|c|c|c|c|}
\hline \multirow{3}{*}{$\begin{array}{c}\text { 外部不経済の } \\
\text { ゾーン間分布 } \\
\text { パターン }\end{array}$} & \multicolumn{4}{|c|}{ 必要な床面積規制 } \\
\hline & \multicolumn{2}{|c|}{$\begin{array}{ll}\text { ゾーン } 1 \\
\end{array}$} & \multicolumn{2}{|c|}{ ゾーン2 } \\
\hline & 居住用 & 事業用 & 居住用 & 事業用 \\
\hline$\Delta G^{H H}-\Delta G^{H D}>0$ & 最低 & 最高 & 最高 & 最低 \\
\hline$\Delta G^{O}-\Delta G^{\alpha H}>0$ & 容積 & 容積 & 容積 & 容積 \\
\hline
\end{tabular}
い. よって必要な政策は $\tilde{F}^{2 f}>0$ となる政策である。 上記の結果をまとめるとケース 1)の場合のゾーン 別, 用途別の最適床面積規制は $\tilde{F}^{1 h}>0, \quad \tilde{F}^{2 f}<0$, $\tilde{F}^{1 h}<0 \quad \tilde{F}^{2 f}>0$ となる. 表-2 に外部不経済のゾー ン間分布パターンが表-1 のケース 1)について結果 をまとめる。

表-2 最適用途別総床面積規制（表-1 ケース 1)）

表-2から一つの特徴として, 一方のゾーンの居住 用(事業用)床面積には最低容積率規制を行い，もう 一方のゾーンには最高容積率規制を行う必要がある ことがわかる。

外部不経済のゾーン間分布パターンが表-1 のケース 2）の場合, 外部不経済の原因別（居住者の移住と従業者 の従業地移動），帰着先別（居住者と事業所）のゾーン 別分布 $\left(\Delta G^{H H}, \Delta G^{H O}, \Delta G^{O H}, \Delta G^{O O}\right)$ について, さらに複 雑な場合分けが必要となる。この場合の最適規制導出に ついては付録に，結果については表-3に示寸．なお，表一 1 と同様に, これらのケース以外にも $\Delta G^{\text {нH}}=\Delta G^{\text {но }}$ $\Delta G^{o O}=\Delta G^{\text {oH }}$ となるケースもありうる．ただし，これら は, 偶然しか存在しないため, 本研究ではこれらのケー スについては分析を行わない.

ケース 2)の場合の最適規制の特徴としてもケー ス 1)の場合と同様に片方のゾーンの居住用(事業用) 床面積では最高容積率規制を行い，もう一方には必 ず最低容積率規制を行う必要があることがわかる. 結局, 命題 1 のようにまとめられる.

命題 1 （最適用途別容積規制）.用途ごとに最高容 積率規制だけでなく最低容積率规制が同時に必要で ある、なお，どちらのン゙ーンに最低（あるいは最 高）容積率規制を行うべきかは表-2 および表-3に 整理された「外部不経済のゾーン間分布パターン」 に依存する。 


\begin{tabular}{|c|c|c|}
\hline \multirow{2}{*}{$\begin{array}{c}\text { 外部不経済の } \\
\text { ゾーン間分布パターン }\end{array}$} & \multicolumn{2}{|c|}{ 必要な居住用床面積規制 } \\
\hline & ゾーン 1 & ゾーン 2 \\
\hline$\left|\left(\Delta G^{H H}-\Delta G^{H O}\right) \frac{d N^{1}}{d \overline{\bar{F}}^{1 h}}\right|>$ & 最低 & 最高 \\
\hline$\left|\left(\Delta G^{\text {ОО }}-\Delta G^{\text {ОН }}\right) \frac{d L^{1}}{d \overline{\bar{F}}^{1 h}}\right|$ & 容積 & 容積 \\
\hline$\left|\left(\Delta G^{H H}-\Delta G^{H O}\right) \frac{d N^{1}}{d \bar{F}^{1 h}}\right|<$ & 最高 & 最低 \\
\hline$\left|\left(\Delta G^{\text {ОО }}-\Delta G^{\text {ОН }}\right) \frac{d L^{1}}{d \overline{\bar{F}}^{1 h}}\right|$ & 容積 & 容積 \\
\hline \multirow{2}{*}{$\begin{array}{c}\text { 外部不経済の } \\
\text { ゾーン間分布パターン }\end{array}$} & \multicolumn{2}{|c|}{ 必要な事業用床面積規制 } \\
\hline & ゾーン 1 & ゾーン 2 \\
\hline$\left|\left(\Delta G^{H H}-\Delta G^{H O}\right) \frac{d N^{1}}{d \overline{\bar{F}}^{1 f}}\right|<$ & 最低 & 最高 \\
\hline$\left|\left(\Delta G^{\text {Oо }}-\Delta G^{\text {OH }}\right) \frac{d L^{1}}{d \overline{\bar{F}}^{1 f}}\right|$ & 容積 & 容積 \\
\hline$\left|\left(\Delta G^{\text {нн }}-\Delta G^{H O}\right) \frac{d N^{1}}{d \overline{\bar{F}}^{1 f}}\right|>$ & 是高 & 是低 \\
\hline$\left(\Delta G^{O O}-\Delta G^{O H}\right) \frac{d L^{1}}{d \bar{F}^{1 f}} \mid$ & 容積 & 容積 \\
\hline
\end{tabular}

\section{（3）最適条件式を満たす用途別総敷地面積規制}

敷地面積に関する最適条件式(7d)を満たすには，居住 用の敷地面積供給の限界費用 $\partial x^{i d h} / \partial \overline{\bar{a}}^{i h}$ と事業所用の敷 地面積供給の限界費用 $\partial x^{i d f} / \partial \overline{\bar{a}}^{i f}$ が一致する必要がある.

ここでこの最適条件を市場均衡と比較する．まず用途 別総敷地面積の決定を市場に任せた状態を式(4d)を修正 して表現する．用途別総敷地面積規制が無い，つまり市 場に任せた場合は Developer が敷地面積を用途別に自由 に分割できるので，式(4d)を敷地面積供給量 $\overline{\bar{a}}_{i}^{k}$ を制御変 数として利潤最大化する，そのとき敷地面積に関する利 潤最大化の一階条件式を求めると式(8a)のようになる.

$$
-\partial \pi^{i d k} / \partial \overline{\bar{a}}^{i k}=-\partial x^{i d k} / \partial \overline{\bar{a}}^{i k}=0 \quad(k=h, f) \quad(8 \mathrm{a})
$$

すなわち用途別に総敷地面積の決定を Developer に任せ ると，Developer は敷地面積供給の限界費用が地代と等 しくなるように開発することがわかる。ここで地主はよ り高い付け值の用途に利用する Developer に土地を売る ため, 結果としてゾーンの事業用と居住用の敷地面積の 地代は等しくなる.すなおち

$$
R^{\text {ih }}=R^{\text {if }}
$$

式(8a)，(8b)から以下の式が導かれる.

$$
\partial x^{i d h} / \partial \overline{\bar{a}}^{i h}=\partial x^{i d f} / \partial \overline{\bar{a}}^{i f}=\left(R^{i h}=R^{i f}\right)
$$

結局，市場に用途別総敷地面積の決定を任せた場合， Developer の利潤最大化行動と地主の行動から居住用と
事業所用の敷地面積供給の限界費用が等しくなる．ゆえ に市場均衡において最適条件式(7d)は自然に達成される。

すなわち，用途別総敷地面積規制は行う必要はなく， 市場に任せても最適性が達成されることがわかる。なお， ここでの用途別総敷地面積規制は最適用途別総床面積規 制が行われているもとでの最適規制である. 寸なわち, 最適総床面積規制が行われていないもとで市場に任せた 用途別総敷地面積供給は最適とはならないことに注意す る必要がある． 結局，命題2のようにまとめられる.

命題 2 (最適用途別総敷地面積規制）.用途別総敷 地面積规制は，最適用途別容積规制がなされている 限り必要なく，市場において最適な用途別総敷地面 積が達成される。（用途別容積率規制が最適でなけ れば，用途別総敷地面積規制は有効である.)

\section{4. 結論}

本研究は，2 ゾーンから成る都市を想定し，1)居住用 途および事業用途それぞれのビル総床面積規制，と 2)居 住用途および事業用途それぞれのビルの総敷地面積規制 について最適規制を求めた。

分析の結果，命題 1 として，一方のゾーンの居住用(事 業用)床面積には最低容積率規制を行い，もう一方のゾ一 ンの居住用(事業用)床面積には最高容積率規制を行う必要 があること，および，どちらのゾーンに最低（あるいは 最高）容積率規制を行うべきかの条件を表-2 および表-3 に整理した。また命題 2 として，用途別総敷地面積規制 は規制する必要がないことが分かった。

現行の都市計画では，ほとんどのゾーンで容積率規制 は用途規制と連動して最高容積率規制のみを用いて規制 している．ただし，我が国でも高度利用地区は，最低容 積率規制を行う。都市計画法第 2 章によると「用途地域 内の市街地における土地の合理的かつ健全な高度利用と 都市機能の更新とを図るため、建築物の容積率の最高限 度及び最低限度、建築物の建ぺい率の最高限度、建築物 の建築面積の最低限度並びに壁面の位置の制限を定める 地区」とある．また，米国などでもオレゴン市やバッフ アロー市，そしてコロラドスプリングス市で，低い開発 を防ぐために，最低限度を定めている．本研究は，この ような最低容積率規制を行う理由を外部性最適化の観点 から説明すると共に，広範な適用の必要性を示している。 
用途別総敷地面積規制については，最適用途別床面積 規制が行われていると，市場均衡に任せても最適である. 現行の都市計画では, 用途別総敷地面積規制は用途地域 という形式で必ず行われている.

なお, 本研究のモデルでは, 効用を最大化する居住者 と利潤を最大化する企業という目的関数の異なる 2 種類 の主体を取り扱った．本研究の結論を導くにあたっては， 同質な主体ではないという点のみが本質であり，同様の 結論は, 居住者と企業という区別だけでなく, 居住者で あっても効用関数が異なったり, 所得が異なるなど属性 が異なる居住者の場合にも得られる.

本研究では, 従業者の集積による正の外部性を明示的 に考慮しなかった. しかしながら, 明示的に考慮したと しても, 本研究のモデルに本質的な変更は必要がなく, さらに結論についても本質的な変更はない. 従業者の集 積は一方で交通混雑などの負の外部性も発生させている. したがって，まず，正の外部性が弱い場合，純の外部性 は負になる.このケースは本研究の設定で十分である.

次に, 正の外部性が強く, 負の外部性を上回るケースに ついも, 最高容積率規制と最低容積率規制の両方が必 要であるという結論については変更がなく，その規制す ベきゾーンが入れ替わるだけである.

本研究のモデルは都市を 2 ゾーンにのみ分けている. 一方, 実際の都市は多くのゾーンで構成されている.た だし，多ゾーンは 2 ゾーンに集約することも可能である ため, 本研究の命題 1 および命題 2 にいては, 実際の 都市にも適用可能である. 本研究で仮定した面積の固定 された都市について, 実際の都市として地理的制約から 都市面積を拡大できない Hong Kong や Kathmandu Valley があげられる，また，我が国の線引きされた市街 化区域を対象としていると考えることも可能である.

今後の研究としては，住民や従業者が自ゾーンの外部 不経済のみに影響を与える仮定を緩めて, 都市全体での 住民や従業者の分布に依存する外部不経済の場合の考察 があげられる. 実際, 都市の交通混雑は都市全体の居住 分布に応じて決定する. また, 本研究では固定であった 各ゾーンの大きさも政策変数とした分析が必要である.

\section{付録}

本論で省略した表-1のケース 2）に関して外部不 経済の分布パターン別の最適用途別総床面積規制の 導出を行う.
$\Delta G^{H H}-\Delta G^{H O}>0, \Delta G^{O O}-\Delta G^{O H}<0$ の場合, 式 (7c)の判明している項の正負を項の下に示す.

ゾーン 1 の居住用床面積の変化に対しては以下の 式で示される.

$$
\begin{aligned}
& \frac{\partial B}{\partial \overline{\bar{F}}^{1 h}}=\left(\Delta G^{H H}-\Delta G^{H O}\right) \frac{d N^{1}}{d \overline{\bar{F}}_{(+)}^{1 h}} \\
& -\underset{(-)}{\left(\Delta G^{O O}-\Delta G^{O H}\right)} \frac{d L^{1}}{d \overline{\bar{F}}_{(-)}^{1 h}}+r^{1 h}-\frac{\partial x^{1 d h}}{\partial \overline{\bar{F}}^{1 h}}=0
\end{aligned}
$$

上の式では $r^{1 h}-\partial x^{1 d h} / \partial \overline{\bar{F}}^{1 h}$ の項の正負は判明しない ので，さらに絶対値の大きさによる場合分けを行う. 必要な場合分けは $\left|\left(\Delta G^{H H}-\Delta G^{H O}\right) \frac{d N^{1}}{d \overline{\bar{F}}^{1 h}}\right|$ と $\left|\left(\Delta G^{O O}-\Delta G^{O H}\right) \frac{d L^{1}}{d \overline{\bar{F}}^{1 h}}\right|$ の大小関係である.

$\left|\left(\Delta G^{H H}-\Delta G^{H O}\right) \frac{d N^{1}}{d \overline{\bar{F}}^{1 h}}\right|>\left|\left(\Delta G^{O O}-\Delta G^{O H}\right) \frac{d L^{1}}{d \overline{\bar{F}}^{h}}\right|$ の時, $r^{1 h}-\partial x^{1 d h} / \partial \overline{\bar{F}}^{1 h}$ 以外の項の総和はプラスとなるため, 最適条件式が成立するには, 図-1から, ゾーン 1 の 居住用床面積を市場均衡よりも大きく規制しなけれ ばならない。よって必要な政策は最低容積率規制 $\tilde{F}^{1 h}>0$ である.

次にゾーン 2 の居住用床面積規制 $\tilde{F}^{2 h}$ についても 考える. ゾーン 2 の居住用床面積の変化に対して は以下の式で示される.

$$
\begin{aligned}
& \frac{\partial B}{\partial \bar{F}^{2 h}}=\left(\Delta G_{(+)}^{H H}-\Delta G^{H O}\right) \frac{d N^{1}}{d \bar{F}_{(-)}^{2 h}} \\
& -\left(\Delta G_{(-)}^{O O}-\Delta G^{O H}\right) \frac{d L^{1}}{d \overline{\bar{F}}_{(+)}^{2 h}}+r^{2 h}-\frac{\partial x^{2 d h}}{\partial \bar{F}^{2 h}}=0
\end{aligned}
$$

よって必要となる場合分けは $\left|\left(\Delta G^{H H}-\Delta G^{H O}\right) \frac{d N^{1}}{d \overline{\bar{F}}^{2 h}}\right|$ と $\left|\left(\Delta G^{O O}-\Delta G^{O H}\right) \frac{d L^{1}}{d \overline{\bar{F}}^{2 h}}\right|$ の大小 関係である．上でン゙ーン 1 の居住用床面積規制を導 くときに用いた条件と同じ外部不経済のパターンを 考える. すなわち, 式(C2)である.

$$
\left|\left(\Delta G^{H H}-\Delta G^{H O}\right) \frac{d N^{1}}{d \overline{\bar{F}}^{1 h}}\right|>\left|\left(\Delta G^{O O}-\Delta G^{O H}\right) \frac{d L^{1}}{d \overline{\bar{F}}^{h}}\right|
$$

ここで, 次の補題が成立する.この成立を豲密に 証明することも可能である，ただし，直感的にも明 らかな結果であることからここには証明を示さない，

補題 1 . 事業用途容積規制 $\overline{\bar{F}}^{1 f}, \overline{\bar{F}}^{2 f}$ が固定のもとで は, ゾーン 1 の居住者が増加（減少）すれば, ゾー ン1の労働者は必ず減少（増加）する.

ここで，補題 1 の関係を式で表現するために， $L^{1}$ の変化が $N^{1}$ に与える影響を $N^{1}=K\left(L^{1}\right)$ という関数 


$$
\begin{aligned}
& \text { で表すと, 次式となる. } \\
& d N^{1}=K_{(-)} d L^{1} \\
& \text { この式を式(C2)に代入すると } \\
& \left|\Delta G^{H H}-\Delta G^{\text {Hо }}\right|\left|K_{L^{1}} \frac{d L^{1}}{d \overline{\bar{F}}^{1 h}}\right|>\left|\Delta G^{O O}-\Delta G^{O H}\right| \frac{d L^{1}}{d \overline{\bar{F}}^{1 h}} \mid \\
& \text { であり, 結局 }\left|\Delta G^{H H}-\Delta G^{H O}\right|\left|K_{L^{1}}\right|>\left|\Delta G^{O O}-\Delta G^{O H}\right| \text { となる. } \\
& \text { 両辺に, } d L^{1} / d \overline{\bar{F}}^{2 h} \text { を乗じると， } \\
& \left|\Delta G^{H H}-\Delta G^{H O}\right|\left|K_{L^{1}} \frac{d L^{1}}{d \overline{\bar{F}}^{2 h}}\right|>\left|\Delta G^{O H}-\Delta G^{O O}\right|\left|\frac{d L^{1}}{d \overline{\bar{F}}^{2 h}}\right| \text { となり, } \\
& \text { 式(A11)を代入すると式(C3)となる. } \\
& \left|\Delta G^{H H}-\Delta G^{H O}\right|\left|\frac{d N^{1}}{d \overline{\bar{F}}^{2 h}}\right|>\left|\Delta G^{O H}-\Delta G^{O O}\right|\left|\frac{d L^{1}}{d \overline{\bar{F}}^{2 h}}\right| \\
& \text { すなわち，条件式（C2）と(C3)は同值である. 式 } \\
& \text { (C3) が成立するとき, 最適条件式 (C1) の } \\
& r^{2 h}-\partial x^{2 d h} / \partial \overline{\bar{F}}^{2 h} \text { 以外の項の総和は負になる. したがっ } \\
& \text { て, 最適条件式が成立するためには } r^{2 h}-\partial x^{2 d h} / \partial \overline{\bar{F}}^{2 h}>0 \\
& \text { となることが必要である. 図- } 1 \text { から,ゾーン } 2 \text { の }
\end{aligned}
$$

謝辞: 本研究について, 若名の查読者から多くの有 益な指摘を頂いた。ここに記して感謝する.

\section{参考文献}

1) R. J. Arnott, J. G. MacKinnon : Measuring the costs of height restrictions with a general equilibrium model, Regional Science and Urban Economics 7
(1977) 359-375.

2) A. Bertaud, J.K. Bruecker : Analyzing buildingheight restriction: predicted impacts and welfare costs, Regional science and Urban Economics 7, (2005) 109-125.

3) P. N. Courant : On the effect of fiscal zoning on land and housing values, Journal of Urban Economics 3, (1976) 88-94.

4) R. E. Grieson, J.R.. White : The effects of zoning on structure and land markets, Journal of Urban Economics 10, (1981) 271-285.

5) W. C. Wheaton : Land Use and density in cities with congestion, Journal of Urban Economics 43, (1998) 258-272 .

6) 河野達仁，金子貴之，森杉壽芳：最適土地利用 密度規制の設計に関する基礎的研究, 土木学会 論文集 No.695/IV-54, (2002) 77-90.

7) T. Kono, T. Kaneko, H. Morisugi : Necessity of Minimum Floor Area Ratio Regulation: a Secondbest Policy, Annals of Regional Science (Published online: 8 October 2008), doi:10.1007/s00168-00802690.

8) K. Joshi and T. Kono : Optimization of Floor Area Ratio Regulation in a Growing City, Regional Science and Urban Economics 39 (2009) 502-511

9) Rossi-Hansberg, E.,. Optimal urban land use and zoning. Review of Economic Dynamics 7, (2003) 69-106

10) M. Fujita : Neighborhood externalities and traffic congestion, Urban Economic Theory, Cambridge University Press, (1989).

\section{最適な容積規制と用途規制：各用途および用途間に発生する外部不経済の適正化*}

$$
\text { 河野達仁**・森田有一*** }
$$

都市部の土地は様々な用途に利用されており, 発生する外部不経済(e.g., 混雑, 騒音)の質・量は用 途ごとに異なる。また，その外部性は，様々な用途の主体に異なる影響を与える。本研究は，これら の外部不経済を適正化する容積規制と用途規制を考察する。具体的には 2 ゾーンから成る都市を想定 し，1)居住および事業用途それぞれのビル総床面積規制，と 2)居住および事業用途それぞれのビル の総敷地面積規制について最適規制を求める。その結果，用途ごとに片方のゾーンに最高容積率規制， もう一方のゾーンに最低容積率規制を行う必要性を示す。一方，最適容積率が課されていると用途別 総敷地面積規制は必要なく，市場において最適な用途別総敷地面積が達成されることを示す.

\section{A Study on the Design of Optimal Floor Area and Land Use Regulation *}

By Tatsuhito KONO **, Yuichi MORITA ***

CBD areas are used for some purposes such as business and residences by several kinds of agents (e.g., office workers and residents). The external diseconomies generated by such agents differ in quality and quantity between the kinds of agents. This study examines how to impose Floor Area Ratio (FAR) regulations and land use zoning in the presence of external diseconomies arising from population density, e.g., congestion and noise. We assume a city with two zones. Buildings in the city are used for either residence or business. Results indicate that there is a need for "maximum FAR regulations," in addition to "minimum FAR regulations". And there is no need for "land use zoning." 